\title{
ВІДТВОРЕННЯ ПРОДУКТИВНОСТІ ГРУНТІВ В ПРИРОДНИХ ТА ВИРОБНИЧИХ УМОВАХ
}

Предоляк О. М., к. с.-г. наук, завідувач відділом

Круглик С. Г., науковий співробітник

Нагорна О. В., провідний інженер

Плотніцька А. В., молодший науковий співробітник

Україна, Київська обл.. Києво-Святошинський р-н., смт. Чабани

Національний університет біоресурсів і природокористування Украӥни

Украӥнська лабораторія якості та безпеки продукиї АПК

DOI: https://doi.org/10.31435/rsglobal_ws/12072018/6012

\section{ARTICLE INFO}

Received: 10 May 2018

Accepted: 15 June 2018

Published: 12 July 2018

\section{KEYWORDS}

Soil organic matter; biologization of agriculture;

humus;

potential humus renewing ability;

fallow;

tillage systems;

fertilization variants.

\begin{abstract}
It was investigated the effect of long fallow and systematic minimizing tillage on organic matter in soils and its potential renewing ability. It was investigated the factors of influence on the mineralization and humification of soil organic matter. Using of energy-saving technologies and alternative organic fertilizers increases soil organic matter and gives the results close to the fallow values. It was found that soil fertility performance to the fallow levels are possible with prolonged use of organic fertilizers and minimize soil tillage.
\end{abstract}

Citation: Предоляк О. М., Круглик С. Г., Нагорна О. В., Плотніцька А. В. (2018) Vidtvorennia Produktyvnosti Gruntiv v Pryrodnykh ta Vyrobnychykh Umovakh. World Science. 7(35), Vol.2. doi: 10.31435/rsglobal_ws/12072018/6012

Copyright: (C) 2018 Предоляк О. М. Круглик С. Г. Нагорна О. В. Плотніцька А. В. This is an openaccess article distributed under the terms of the Creative Commons Attribution License (CC BY). The use, distribution or reproduction in other forums is permitted, provided the original author(s) or licensor are credited and that the original publication in this journal is cited, in accordance with accepted academic practice. No use, distribution or reproduction is permitted which does not comply with these terms.

Вступ. Родючість грунту обумовлюється інтенсивністю кругообігу речовин і енергії в системі «грунт-рослина». Потрібно також зазначити, що родючість грунту реалізується лише в конкретному біогеоценозі чи агроценозі. Прянішніков Д. М. (1963) відмічав, що поняття «родючість» невід’ємне від культури. Отже, родючість - це відповідність умов грунтового середовища потребам рослин, а тому для іiі характеристики потрібно знати як показники властивостей і режимів грунту, так і біологічні особливості культур [5, с. 35]. Найважливішою складовою грунту і показником його родючості $\epsilon$ органічна речовина, яка на 85-90 \% представлена гумусом. Вона впливає майже на всі показники родючості і проходить у грунті на етапі Малого біологічного кругообігу речовин складний шлях перетворень, що в основному визначається поняттям «гумусний стан» $[8$, с. 1$]$.

Найбільш типовою складовою будь-якої екосистеми $є$ наземна рослинність і тваринна сукупність, які взаємодіють між собою і з оточуючим середовищем, у першу чергу з грунтом. Ці складові розміщуються на поверхні землі в залежності від існування і функціонування грунтових компонентів екосистеми. Роль коренів рослин, а також різноманітної мікро- і мезофауни в приповерхневому шарі очевидна [3, с. 43].

Органічна частина грунту представлена складною системою різноманітних речовин, динамічність якої залежить від надходження до грунту рослинних решток і зміни їх під впливом 
різних груп мікроорганізмів та представників фауни [4]. Потенційним джерелом органічної речовини грунту є всі компоненти біоценозу, які беруть участь в грунтоутворюючих процесах. Це рештки рослин, тварин, мікроорганізмів і продукти їх метаболізму. Основним матеріалом для формування грунтової органічної речовини є саме рослинні рештки, які за масою значно переважають усі інші джерела. Помітний вклад в іiі формуванні грунтових тварин i мікроорганізмів визначається високим вмістом у них залишків білкових речовин [6, с. 255].

У цілинних екосистемах 3 високою продуктивністю ценозів щорічно відмирає значна кількість біомаси. На певному етапі розвитку рослинної асоціації швидкість надходження рослинних решток у підстилку перевищує швидкість їх розкладання. Тому на поверхні грунту накопичується повстина, яка виконує роль мульчі, захищаючи грунт від несприятливих впливів. Повстина разом з відмираючою кореневою системою $є$ основним джерелом надходження в грунт свіжої органічної речовини. Причому майже вся свіжа органічна речовина надходить у верхній, найбільш біологічно активний шар грунту, що зумовлює ії швидку трансформацію і гуміфікацію. Співпадіння зон надходження гумусоутворювачів і найвищої біологічної активності є запорукою збереження запасів гумусу грунту при одночасному інтенсивному кругообігу речовин і енергії $[3$, c. $29 ; 5$, c. 79$]$.

Розклад органічної речовини грунту, створеної автотрофами, відіграє важливу роль у біосфері. Він $є$ одним із ланцюгів біологічного кругообігу речовин, і цей процес забезпечує стійкість біогеоценозів і біосфери в цілому [4, с. 26].

Швидкість розкладу рослинних решток у агроценозах залежить від культури, урожайності, хімічного складу біомаси, способу вирощування сільськогосподарських культур, системи удобрення, попередників, грунтових умов, біологічної активності грунту, метеорологічних факторів та ін. Рядом дослідників показані достовірні відмінності в швидкості розкладу решток різних сільськогосподарських культур, наприклад, бобових, зернових, овочевих [6, с. 142]. Швидкість мінералізації рослинних решток залежно від вмісту в них легкорозчинних органічних речовин була встановлена ще роботами П. А. Костичева, С.Н.Кравкова, В.С. Чумакова. Велику роль при цьому відіграє збагаченість органічної речовини азотом. Рослинні рештки з високим вмістом азоту $(\mathrm{C}: \mathrm{N}<30: 1)$ розкладаються швидше, з низьким (C:N > 50:1) - повільно. Залежність швидкості розкладу від вмісту кальцію зростає 3 розвитком процесу трансформації органічної речовини грунту [2, с.248; 7, с. 147].

Із збільшенням строків розкладу загальна втрата маси рослинних решток зростає, а швидкість розкладу в одиницю часу зменшується. Найбільш інтенсивно мінералізація йде в початковий період розкладу, що відмічено багатьма дослідниками. Високі першочергові втрати пов'язані з біохімічними процесами трансформації, виділенням вуглекислого газу, втратою води і вилуговуванням водорозчинних компонентів [7, с. 344].

Літературні джерела свідчать, що існує суттєвий зв'язок між продуктивністю агроценозів і вмістом та запасами гумусу в грунтах, на яких формуються врожаї культур. Так, за даними Б. С. Носка та співавторів [5, с. 80], у чорноземних грунтах Лісостепу України при збільшеному вмісті гумусу з 3 до 5 \% врожайність зернових збільшувалась відповідно 3 17-20 до 24-28 ц/га, а кукурудзи на зерно - 3 14-17 до 21-26 ц/га. Коефіцієнти кореляції між вмістом та запасами гумусу і врожайністю цукрових буряків становили 0,77-0,83.

Мета досліджень. Метою наших досліджень було розроблення оптимальних шляхів і методів регулювання вмісту гумусу та встановлення взаємозв'язку між надходженням біомаси в грунт та відновленням потенційної здатності до гумусоутворення за різних способів обробітку та варіантів удобрення, на чорноземі типовому малогумусному грубопилуватолегкосуглинковому на лесі в умовах Правобережного Лісостепу України.

Методика досліджень. Дослідження проводились на 10-річному перелозі та стаціонарному досліді на фоні обробітків: оранка (20-22 см); плоскорізний обробіток (10-12 см); плоскорізний обробіток (22-27 см); і варіантів удобрення: без добрив (контроль); Гній 12 т/га + $\mathrm{N}_{55} \mathrm{P}_{45} \mathrm{~K}_{45}$; Солома $1,2 \mathrm{t} / г \mathrm{a}+\mathrm{N}_{12}+$ сидерати $+\mathrm{N}_{55} \mathrm{P}_{45} \mathrm{~K}_{45}$. Повторність досліду трикратна.

Зразки грунту досліджували на базі УЛЯБП АПК НУБіП України. Визначення вмісту загального гумусу й органічної речовини проводили за методом Тюріна в модифікації Сімакова (ДСТУ 4289:2004), потенційну здатність до гумусоутворення - за методом Л. Н. Александрової та О. В. Юрлової.

Результати досліджень. На базі УЛЯБП АПК та на стаціонарному досліді кафедри грунтознавства та охорони грунтів ім. проф. М.К. Шикули нами була визначена маса рослинних решток на різних варіантах удобрення та обробітку в сівозміні за вирощування пшениці озимої, конюшини та цукрового буряку та порівняна 3 масою рослинних решток на перелозі. 3 таблиці 1 
видно, що на перелозі накопичується найбільша кількість як поверхневих, так і кореневих решток. Перевагу над цілиною мала лише конюшина, кореневі рештки якої переважали цілину на 11,7-31,5 \%. Це можна пояснити біологічною особливістю конюшини, яка накопичує значну кореневу масу.

Так, серед трьох культур конюшина мала найбільшу кількість решток на всіх варіантах удобрення та обробітку. Серед обробітків кращі результати мала оранка в рік вирощування конюшини, а при пшениці озимій та цукрових буряках переважав безполицевий мілкий обробіток як на кореневих, так і в поверхневих рештках.

Таблиця 1. Біомаса рослинних решток стаціонарного досліду в НДГ «Великоснітинське» та перелогу

\begin{tabular}{|c|c|c|c|c|c|c|c|c|}
\hline \multirow{3}{*}{ 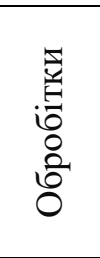 } & \multirow{3}{*}{$\begin{array}{c}\text { Варіанти } \\
\text { удобрення }\end{array}$} & \multicolumn{6}{|c|}{ Кількість рослинних решток, т/га } & \multirow{3}{*}{$\begin{array}{c}\text { Всього } \\
\text { рослинних } \\
\text { решток в } \\
\text { ланці } \\
\text { сівозміни, } \\
\text { т/га } \\
\end{array}$} \\
\hline & & \multicolumn{2}{|c|}{ Конюшина } & \multicolumn{2}{|c|}{$\begin{array}{c}\text { Пшениця } \\
\text { озима }\end{array}$} & \multicolumn{2}{|c|}{$\begin{array}{c}\text { Цукровий } \\
\text { буряк }\end{array}$} & \\
\hline & & $\begin{array}{c}\text { поверх- } \\
\text { неві }\end{array}$ & $\begin{array}{l}\text { коре- } \\
\text { неві }\end{array}$ & $\begin{array}{c}\text { поверх- } \\
\text { неві }\end{array}$ & $\begin{array}{l}\text { коре- } \\
\text { неві }\end{array}$ & $\begin{array}{c}\text { поверх- } \\
\text { неві }\end{array}$ & $\begin{array}{l}\text { коре- } \\
\text { неві }\end{array}$ & \\
\hline \multirow{3}{*}{ 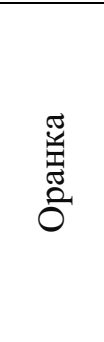 } & $\begin{array}{l}\text { Без добрив } \\
\text { (контроль) }\end{array}$ & 2,97 & 14,85 & 2,28 & 3,17 & 3,56 & - & 28,83 \\
\hline & $\begin{array}{c}\text { Гній 12т/га + } \\
\mathrm{N}_{55} \mathrm{P}_{45} \mathrm{~K}_{45}\end{array}$ & 4,05 & 17,48 & 3,21 & 5,25 & 5,25 & - & 35,24 \\
\hline & $\begin{array}{c}\text { Солома } \\
1,2 \text { т/га + } \mathrm{N}_{10,2} \\
+ \text { сидерати }+ \\
\mathrm{N}_{55} \mathrm{P}_{45} \mathrm{~K}_{45} \\
\end{array}$ & 3,87 & 16,61 & 3,03 & 4,83 & 5,05 & - & 33,39 \\
\hline \multirow{3}{*}{ 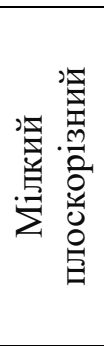 } & $\begin{array}{c}\text { Без добрив } \\
\text { (контроль) }\end{array}$ & 3,01 & 15,04 & 2,18 & 2,97 & 3,63 & - & 26,83 \\
\hline & $\begin{array}{c}\text { Гній } 12 \text { т/га + } \\
\mathrm{N}_{55} \mathrm{P}_{45} \mathrm{~K}_{45} \\
\end{array}$ & 4,01 & 17,12 & 3,27 & 5,39 & 5,43 & - & 35,22 \\
\hline & $\begin{array}{c}\text { Солома } \\
1,2 \text { т/га + } \mathrm{N}_{10,2} \\
+ \text { сидерати }+ \\
\mathrm{N}_{55} \mathrm{P}_{45} \mathrm{~K}_{45} \\
\end{array}$ & 3,81 & 16,64 & 3,16 & 5,14 & 5,16 & - & 33,91 \\
\hline \multirow{3}{*}{ 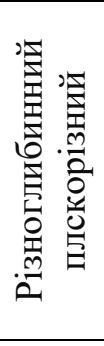 } & $\begin{array}{c}\text { Без добрив } \\
\text { (контроль) }\end{array}$ & 2,99 & 14,93 & 2,24 & 3,09 & 3,65 & - & 26,90 \\
\hline & $\begin{array}{c}\text { Гній 12т/га + } \\
\mathrm{N}_{55} \mathrm{P}_{45} \mathrm{~K}_{45}\end{array}$ & 3,99 & 16,95 & 3,18 & 5,19 & 5,33 & - & 34,64 \\
\hline & $\begin{array}{c}\text { Солома } \\
1,2 \text { т/га }+\mathrm{N}_{10,2} \\
+ \text { сидерати + } \\
\mathrm{N}_{55} \mathrm{P}_{45} \mathrm{~K}_{45} \\
\end{array}$ & 3,84 & 16,58 & 3,21 & 5,24 & 4,84 & - & 33,71 \\
\hline \multicolumn{2}{|r|}{ Переліг } & 6,54 & 13,29 & - & - & - & - & - \\
\hline
\end{tabular}

Одним із основних критеріїв оцінки гумусного стану грунту є його збалансованість або просте відтворення. Ведення збалансованого сільськогосподарського виробництва не тільки запобігає втратам гумусу в грунті, а й, що не менш важливо, створює необхідні запаси свіжого енергетичного матеріалу для біологічних процесів, поповнення складу гумусу і звільнення його азоту для вирощування культур. В орних землях рівні органічних речовин можна регулювати доведенням до максимуму надходження свіжої органічної речовини, зведенням до мінімуму процесу розкладання або внесенням у грунт ззовні органічних залишків. У кожному випадку буде досягнутий новий стаціонарний рівень вмісту органічних речовин у грунті.

Необхідність відтворення органічної речовини чорноземних грунтів обумовлена також меншим її вмістом у порівнянні з оптимальним значенням. Органічна речовина грунту $є$ його основним енергетичним запасом, а ії лабільні форми більш доступні рослинам для мінерального живлення, ніж власне гумусові речовини. Напіврозкладені рослинні рештки, які уже представляють собою органічну речовину грунту, але ще не є гумусовими речовинами, підсилюють мікробіологічні процеси в товщі грунту. Тому, коли на сучасному етапі 
землеробства склався дефіцит традиційних органічних добрив, перспективним i загальнодоступним стає використання супутньої продукції, в першу чергу, соломи, а також заробка сидератів. Вони поповнюють органічну речовину грунту, і ще на ранніх стадіях гуміфікації забезпечують рослини елементами живлення.

3 таблиці 2 видно, що на вміст органічної речовини значний вплив мали як варіанти удобрення, так і обробіток грунту. Внесення різних видів органічних добрив сприяло збільшенню показника органічної речовини на всіх варіантах обробітку. Найбільш ефективним було внесення гною в нормі 12 т/га, це сприяло ії̈ збільшенню на 0,76-0,88 \%. Внесення гною разом з соломою на фоні мінеральних добрив збільшило вміст органічної речовини на $0,67-0,70 \%$. Застосування мілкого безполицевого обробітку на варіанті, де вносили 12 т/га на фоні мінеральних добрив, дало змогу наблизити їі рівень до вмісту на перелозі в шарі 0-10 см.

Відповідно з глибиною різниця між перелогом і стаціонарними варіантами ставала значнішою. Серед варіантів обробітку найкращим у верхніх горизонтах був мілкий, оскільки сприяв накопиченню і збереженню органічної речовини на поверхні грунту.

Таблиця 2. Вміст органічної речовини та гумусу чорнозему типового залежно від системи удобрення та обробітку

\begin{tabular}{|c|c|c|c|c|c|c|c|c|c|}
\hline \multirow{3}{*}{$\begin{array}{c}\text { Обробіток } \\
\text { грунту }\end{array}$} & \multirow{3}{*}{$\begin{array}{c}\text { Варіанти } \\
\text { удобрення }\end{array}$} & \multicolumn{8}{|c|}{ Глибина відбору зразків, см } \\
\hline & & \multicolumn{2}{|c|}{$0-10$} & \multicolumn{2}{|c|}{$10-20$} & \multicolumn{2}{|c|}{$20-30$} & \multicolumn{2}{|c|}{$30-40$} \\
\hline & & $\begin{array}{c}\text { орган. } \\
\text { реч., } \\
\%\end{array}$ & $\begin{array}{c}\text { гумус, } \\
\%\end{array}$ & $\begin{array}{c}\text { орган. } \\
\text { реч., } \\
\%\end{array}$ & $\begin{array}{c}\text { гумус, } \\
\%\end{array}$ & $\begin{array}{c}\text { орган. } \\
\text { реч., } \\
\%\end{array}$ & $\begin{array}{c}\text { гумус, } \\
\%\end{array}$ & $\begin{array}{c}\text { орган. } \\
\text { реч., } \\
\%\end{array}$ & $\begin{array}{c}\text { гумус, } \\
\%\end{array}$ \\
\hline 1 & 2 & 3 & 4 & 5 & 6 & 7 & 8 & 9 & 10 \\
\hline \multirow{5}{*}{ 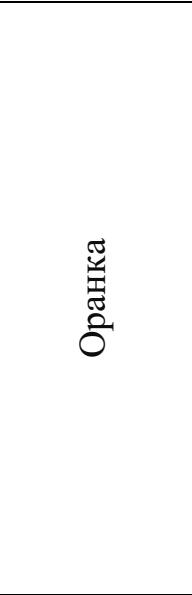 } & Контроль & 3,35 & 3,18 & 3,27 & 3,12 & 3,14 & 3,04 & 3,00 & 2,83 \\
\hline & $\begin{array}{l}\text { Гній } 12 \text { т/га } \\
+\mathrm{N}_{55} \mathrm{P}_{45} \mathrm{~K}_{45} \\
\end{array}$ & 4,23 & 4,00 & 4,20 & 4,01 & 4,16 & 3,94 & 3,58 & 3,43 \\
\hline & $\begin{array}{c}\text { Гній } 6 \text { т/га } \\
+ \text { солома } \\
1,2 \text { т/га + } \\
\mathrm{N}_{67} \mathrm{P}_{45} \mathrm{~K}_{45} \\
\end{array}$ & 4,05 & 3,78 & 4,02 & 3,77 & 3,97 & 3,73 & 3,50 & 3,30 \\
\hline & $\begin{array}{c}\text { Солома } 2,4 \\
\text { т/га }+ \\
\mathrm{N}_{79} \mathrm{P}_{45} \mathrm{~K}_{45} \\
\end{array}$ & 3,97 & 3,67 & 3,90 & 3,66 & 3,87 & 3,62 & 3,48 & 3,27 \\
\hline & $\begin{array}{c}\text { Солома 1,2 } \\
\text { т/га }+ \\
\text { сидерати }+ \\
\mathrm{N}_{67} \mathrm{P}_{45} \mathrm{~K}_{45}\end{array}$ & 3,88 & 3,62 & 3,83 & 3,57 & 3,83 & 3,59 & 3,52 & 3,31 \\
\hline \multirow{5}{*}{ 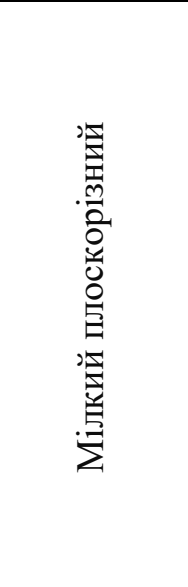 } & Контроль & 3,45 & 3,28 & 3,13 & 2,98 & 3,09 & 2,93 & 2,93 & 2,81 \\
\hline & $\begin{array}{l}\text { Гній } 12 \text { т/га } \\
+\mathrm{N}_{55} \mathrm{P}_{45} \mathrm{~K}_{45} \\
\end{array}$ & 4,32 & 4,08 & 4,11 & 3,88 & 3,96 & 3,73 & 3,51 & 3,28 \\
\hline & $\begin{array}{c}\text { Гній } 6 \text { т/га } \\
+ \text { солома } \\
1,2 \text { т/га }+ \\
\mathrm{N}_{67} \mathrm{P}_{45} \mathrm{~K}_{45} \\
\end{array}$ & 4,12 & 3,81 & 4,04 & 3,73 & 3,97 & 3,68 & 3,40 & 3,19 \\
\hline & $\begin{array}{c}\text { Солома } 2,4 \\
\text { т/га }+ \\
\mathrm{N}_{79} \mathrm{P}_{45} \mathrm{~K}_{45} \\
\end{array}$ & 3,76 & 3,48 & 3,72 & 3,43 & 3,58 & 3,29 & 3,47 & 3,25 \\
\hline & $\begin{array}{c}\text { Солома 1,2 } \\
\text { т/га }+ \\
\text { сидерати }+ \\
\mathrm{N}_{67} \mathrm{P}_{45} \mathrm{~K}_{45}\end{array}$ & 4,00 & 3,73 & 3,94 & 3,67 & 3,88 & 3,59 & 3,54 & 3,32 \\
\hline
\end{tabular}


Продовження таблиці 2.

\begin{tabular}{|c|c|c|c|c|c|c|c|c|c|}
\hline 1 & 2 & 3 & 4 & 5 & 6 & 7 & 8 & 9 & 10 \\
\hline \multirow{5}{*}{$\begin{array}{c}\text { Різноглибинний } \\
\text { плоскорізний }\end{array}$} & Контроль & 3,46 & 3,23 & 3,31 & 3,15 & 3,13 & 2,98 & 2,92 & 2,75 \\
\hline & $\begin{array}{c}\text { Гній } 12 \\
\text { т/га + } \\
\mathrm{N}_{55} \mathrm{P}_{45} \mathrm{~K}_{45}\end{array}$ & 4,22 & 3,95 & 4,08 & 3,82 & 3,99 & 3,77 & 3,54 & 3,32 \\
\hline & $\begin{array}{c}\text { Гній } 6 \\
\text { т/га }+ \\
\text { солома } \\
1,2 \text { т/га }+ \\
\mathrm{N}_{67} \mathrm{P}_{45} \mathrm{~K}_{45} \\
\end{array}$ & 4,16 & 3,91 & 4,06 & 3,84 & 3,95 & 3,72 & 3,54 & 3,37 \\
\hline & $\begin{array}{c}\text { Солома } \\
2,4 \text { т/га }+ \\
\mathrm{N}_{79} \mathrm{P}_{45} \mathrm{~K}_{45}\end{array}$ & 3,89 & 3,63 & 3,84 & 3,59 & 3,79 & 3,55 & 3,48 & 3,29 \\
\hline & $\begin{array}{c}\text { Солома } \\
1,2 \text { т/га }+ \\
\text { сидерати } \\
+ \\
\mathrm{N}_{67} \mathrm{P}_{45} \mathrm{~K}_{45}\end{array}$ & 3,99 & 3,70 & 3,91 & 3,63 & 3,86 & 3,59 & 3,20 & 3,03 \\
\hline Перел & & 4,33 & 3,93 & 4,27 & 3,91 & 4,20 & 3,88 & 3,89 & 3,63 \\
\hline
\end{tabular}

При оранці органічні добрива заорювались, що сприяло швидкому розкладу органічної речовини і їі мінералізації, і відповідно вищому вмісту в шарі 20-30 см.

Для збільшення вмісту i запасів гумусу в грунтах Лісостепу необхідно проводити трансформацію сільськогосподарських угідь 3 метою зменшення їх розораності, а також шукати шляхи збільшення надходження свіжої органічної речовини в грунт при відмові від внесення гною.

Одним із прийомів оцінки гумусного режиму грунту $є$ визначення потенційної здатності до гумусоутворення, яка встановлюється за різницею між вмістом органічної речовини, яка визначається без відбору рослинних решток $\left(\mathrm{C}_{\text {орг. }}\right)$, i власне гумусових речовин $\left(\mathrm{C}_{\text {гум. }}\right)$.

Узагальнення результатів досліджень (табл. 3) дало змогу встановити, що внесення традиційних органічних добрив (гною) на фоні мінеральних мало найбільший позитивний ефект у порівнянні з іншими варіантами по вмісту вуглецю гумусу та органічної речовини. Але якщо порівняти їх з даними на перелозі, то переважає останній. Це ще раз підтверджує, що на залужених ділянках краще проходять процеси гумусоутворення, ніж на орних землях. Реальне накопичення гумусу в грунті в результаті гуміфікації рослинних решток можливе при умові, коли різниця між $\mathrm{C}_{\text {орг }}$ i $\mathrm{C}_{\text {гум }}$ перевищує $0,5 \%$. За меншої різниці утворення гумусових речовин не перекриває його мінералізацію, i, відповідно, не відбувається його накопичення. Аналізуючи потенційну здатність до гумусоутворення чорноземів типових, було встановлено, що різниця найвища на перелозі - 0,23\%, проте вона не досягла того мінімуму (0,5 \%), що визначають вказані автори.

Серед обробітків найкращим $є$ мілкий плоскорізний з варіантом гною 6 т/га + соломи 1,2 т/га $+\mathrm{N}_{67} \mathrm{P}_{45} \mathrm{~K}_{45}$, різниця становить $0,18 \%$, на оранці найбільш ефективним був варіант: солома $2,4 \mathrm{t} / г \mathrm{a}+\mathrm{N}_{20,4}+\mathrm{N}_{55} \mathrm{P}_{45} \mathrm{~K}_{45}-0,17 \%$, а на різноглибинному плоскорізному - варіант 3 соломою і сидератами - $0,17 \%$.

Така різниця обумовлена внесенням соломи у високих нормах, розкладання якої може проходити роками, i для ії гуміфікації необхідна достатня кількість елементів живлення та висока мікробіологічна активність грунту. 
Таблиця 3. Середній вміст вуглецю гумусу (за Тюріним) та вуглецю органічної речовини (за Александровою-Юрловою) чорнозему типового залежно від варіантів удобрення та обробітку

\begin{tabular}{|c|c|c|c|c|c|c|c|}
\hline \multirow{2}{*}{$\begin{array}{l}\text { Обробіток } \\
\text { грунту }\end{array}$} & \multirow{2}{*}{ Варіант удобрення } & \multicolumn{3}{|c|}{$\mathrm{C}_{\text {орг. }}, \%$ в шарі, см } & \multicolumn{3}{|c|}{$\mathrm{C}_{\text {гум., }} \%$ в шарі, см } \\
\hline & & $0-10$ & $10-20$ & $20-30$ & $0-10$ & $10-20$ & $20-30$ \\
\hline \multirow{5}{*}{ 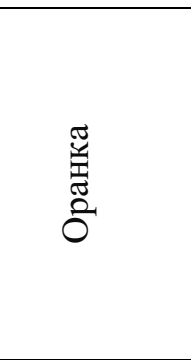 } & Без добрив (контроль) & 1,94 & 1,90 & 1,82 & 1,84 & 1,81 & 1,76 \\
\hline & Гній 12 т/га $+\mathrm{N}_{55} \mathrm{P}_{45} \mathrm{~K}_{45}$ & 2,45 & 2,44 & 2,41 & 2,32 & 2,33 & 2,29 \\
\hline & $\begin{array}{c}\text { Гній } 6 \text { т/га + солома } 1,2 \mathrm{~T} / г \mathrm{a} \\
+\mathrm{N}_{10,2}+\mathrm{N}_{55} \mathrm{P}_{45} \mathrm{~K}_{45}\end{array}$ & 2,35 & 2,33 & 2,30 & 2,19 & 2,19 & 2,16 \\
\hline & $\begin{array}{c}\text { Солома } 2,4 \text { т/га }+ \\
\mathrm{N}_{20,4}+\mathrm{N}_{55} \mathrm{P}_{45} \mathrm{~K}_{45}\end{array}$ & 2,30 & 2,26 & 2,24 & 2,13 & 2,12 & 2,10 \\
\hline & $\begin{array}{c}\text { Солома 1,2 т/га }+\mathrm{N}_{10,2}+ \\
\text { сидерати }+\mathrm{N}_{55} \mathrm{P}_{45} \mathrm{~K}_{45}\end{array}$ & 2,25 & 2,22 & 2,22 & 2,10 & 2,07 & 2,08 \\
\hline \multirow{5}{*}{ 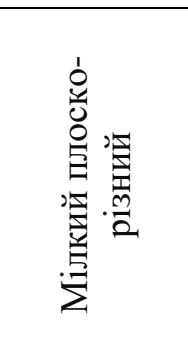 } & Без добрив (контроль) & 2,00 & 1,82 & 1,79 & 1,90 & 1,73 & 1,70 \\
\hline & Гній 12т/га $+\mathrm{N}_{55} \mathrm{P}_{45} \mathrm{~K}_{45}$ & 2,51 & 2,38 & 2,30 & 2,37 & 2,25 & 2,16 \\
\hline & $\begin{array}{c}\text { Гній } 6 \text { т/га + солома } 1,2 \mathrm{~T} / г \mathrm{a} \\
+\mathrm{N}_{10,2}+\mathrm{N}_{55} \mathrm{P}_{45} \mathrm{~K}_{45}\end{array}$ & 2,39 & 2,34 & 2,30 & 2,21 & 2,16 & 2,16 \\
\hline & $\begin{array}{c}\text { Солома 2,4 т/га }+\mathrm{N}_{20,4}+ \\
\mathrm{N}_{55} \mathrm{P}_{45} \mathrm{~K}_{45}\end{array}$ & 2,18 & 2,16 & 2,08 & 2,02 & 1,99 & 1,91 \\
\hline & $\begin{array}{c}\text { Солома 1,2 т/га }+\mathrm{N}_{10,2}+ \\
\text { сидерати }+\mathrm{N}_{55} \mathrm{P}_{45} \mathrm{~K}_{45}\end{array}$ & 2,32 & 2,29 & 2,25 & 2,16 & 2,13 & 2,08 \\
\hline \multirow{5}{*}{ 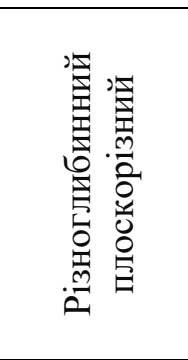 } & Без добрив (контроль) & 2,01 & 1,92 & 1,82 & 1,87 & 1,83 & 1,73 \\
\hline & Гній 12 т/га $+\mathrm{N}_{55} \mathrm{P}_{45} \mathrm{~K}_{45}$ & 2,45 & 2,37 & 2,31 & 2,29 & 2,22 & 2,19 \\
\hline & $\begin{array}{c}\text { Гній } 6 \text { т/га + солома } 1,2 \text { т/га } \\
+N_{10,2}+N_{55} P_{45} \mathrm{~K}_{45}\end{array}$ & 2,41 & 2,35 & 2,29 & 2,27 & 2,23 & 2,16 \\
\hline & $\begin{array}{c}\text { Солома } 2,4 \mathrm{~T} / \text { га }+\mathrm{N}_{20,4}+ \\
\mathrm{N}_{55} \mathrm{P}_{45} \mathrm{~K}_{45}\end{array}$ & 2,26 & 2,23 & 2,20 & 2,11 & 2,08 & 2,08 \\
\hline & $\begin{array}{c}\text { Солома } 1,2 \mathrm{t} /{ }^{2} \mathrm{a}+\mathrm{N}_{10,2}+ \\
\text { сидерати }+\mathrm{N}_{55} \mathrm{P}_{45} \mathrm{~K}_{45}\end{array}$ & 2,31 & 2,27 & 2,24 & 2,15 & 2,11 & 2,08 \\
\hline & Переліг & 2,51 & 2,48 & 2,44 & 2,28 & 2,27 & 2,25 \\
\hline
\end{tabular}

В той же час із гноєм вносяться напівгуміфіковані та напіврозкладені органічні рештки, які швидше і легше переходять у гумусові речовини. Невелика різниця на перелозі $(0,23 \%)$ пов'язана, в першу чергу, з високою біологічною активністю чорнозему типового і порівняно невеликим періодом його природного використання, що не дало можливості накопичитись достатній кількості поверхневих і кореневих решток.

Висновки. У відновленні гумусу грунту за його сільськогосподарського використання беруть участь рослинні рештки, кількість яких залежить від біологічних особливостей культур та удобрення. Найбільше їх надходить під конюшиною, менше - під пшеницею озимою і ще менше - під буряками цукровими.

Системи обробітку мало впливали на кількість рослинних решток, а удобрення збільшувало їх надходження в грунт на 4,6-8,4 т/га. Найбільше рослинних решток щорічно накопичується на перелозі - 19,8 т/га. Рослинні рештки й органічні добрива сприяли зростанню потенційної здатності грунту до гумусоутворення. Найвищою вона була за мілкого плоскорізного обробітку із внесенням 12 т/га гною й мінеральних добрив, але не досягла значень перелогу. 


\section{ЛІТЕРАТУРА}

1. Багаутдинов, Ф. Я. Состав и трансформация органического вещества почв. / Ф. Я. Багаутдинов, Ф. Х. Хазиев - Уфа: Гилием, 2000. - 197 с.

2. Бучкина, Н. П. Устойчовое управление Органическим веществом почв / Н. П. Бучкина, Б. Д. Соан // Почвоведение. - 2001. - № 2. - С. 248-250.

3. Гришина, Л. А. Трансформация органического вещества почв / Л. А. Гришина, Г. Н. Коцик, М. И. Макаров. - М.: Колос, 1990. - 87 с.

4. Куприченков, М. Т. Солома - ценное органическое удобрение. / М. Т. Куприченков, Т. Н. Антонова, А. А. Головиков // Земледелие. -2000. - №5. - С.26-28.

5. Носко, Б. С. Особливості антропогенної еволюції поживного режиму чорноземів / Б. С. Носко // Вісн. ХНАУ - 2008. - № 1. - С. 79-84.

6. Тейт, Р. Органическое вещество почвы: биологические и экологические аспекты / Р. Тейт. - М.: Мир, 1991. - $400 \mathrm{c.}$

7. Шикула, М. К. Відтворення родючості грунтів у грунтозахисному землеробстві / М. К. Шикула. - К.: Оранта, 1998. - 680с.

8. Электронная библиотека научно-образовательной, финансовой и художественной литературы [Електронний ресурс] / Режим доступу: http://bo0k.net/index.php?p=achapter\&bid=21376\&chapter=1 